Marek Derenowski

Uniwersytet im. Adama Mickiewicza w Poznaniu

Państwowa Wyższa Szkoła Zawodowa w Koninie

dereno@icpnet.pl

\title{
WPŁYW PRAKTYK NAUCZYCIELSKICH NA ROZWÓJ REFLEKSYJNOŚCI STUDENTÓW FILOLOGII ANGIELSKIEJ ORAZ NA ICH DALSZE DECYZJE ZWIAZZANE $Z$ WYBOREM ZAWODU NAUCZYCIELA
}

The influence of teaching practice on the development of reflectivity among English philology students and on decisions concerning their future teaching careers

Taking part in teaching practice is supposed to help students of English philology make the right decisions concerning their future teaching careers. During their third year of studies they conduct 45 lessons individually. During these teaching hours students have a unique opportunity to put their theoretical knowledge into practice in the classroom and decide if they really want to become teachers in the future. The study presents data obtained from a short questionnaire and group interviews conducted among philology students after their teaching practice. It focuses on the students' opinions concerning the influence of teaching practice on the development of reflectivity and on the choice of future career. Additionally, students were asked about the possible reasons influencing their decisions about the future.

Keywords: teaching practice, reflectivity, influence on career choice, young teacher

Słowa kluczowe: praktyki nauczycielskie, refleksyjność, wpływ na wybór zawodu, młody nauczyciel 


\section{Wstęp}

Założenia reformy systemu edukacji w Polsce jasno określają zadania ogólne szkoły, w których stwierdza się między innymi, że nauczyciele powinni dążyć do wszechstronnego (wielokierunkowego) rozwoju ucznia jako nadrzędnego celu pracy edukacyjnej. Edukacja szkolna postrzegana jest jako harmonijna realizacja zadań nauczycielskich w zakresie nauczania, kształcenia umiejętności językowych, a także wychowania (http://www.wbc.poznan.pl/Content/9794/ch02s04.html). Aby sprostać tym oczekiwaniom, proces kształcenia przyszłych nauczycieli musi zostać wzbogacony o umiejętność refleksji, dzięki której przyszli nauczyciele będą mogli dostrzegać i modyfikować swoje codzienne zachowanie. Ważność refleksji w kształceniu nauczycieli podkreśla Rozporządzenie Ministra Nauki i Szkolnictwa Wyższego z dnia 17 stycznia 2012 r. w sprawie standardów kształcenia przygotowującego do wykonywania zawodu nauczycieli, w którym stwierdza się, że absolwent posiada cechy refleksyjnego praktyka, ma świadomość poziomu swojej wiedzy i umiejętności; rozumie potrzebę ciągłego dokształcania się zawodowego i rozwoju osobistego oraz dokonuje oceny własnych kompetencji i doskonali umiejętności w trakcie realizowania działań pedagogicznych (dydaktycznych, wychowawczych i opiekuńczych). Jedną z doskonałych okazji rozwijania własnej refleksyjności jest systematyczne uczestnictwo w praktykach nauczycielskich. Podczas obserwacji i samodzielnego prowadzenia zajęć lekcyjnych studenci nabywają wiedzę niezbędną do podjęcia w przyszłości świadomej decyzji o podjęciu zawodu nauczyciela. Nie ma przecież nic gorszego niż nauczyciel z przypadku, który podejmuje pracę bez uprzedniego zaznajomienia się ze specyfiką zawodu. Oczywiście, należy zdawać sobie sprawę ze złożoności zawodu nauczyciela, i oczywistym wydaje się stwierdzenie, że podczas praktyk nie dowiemy się wszystkiego o zawodzie nauczyciela. Jednakże praktyki nauczycielskie to doskonałe miejsce na weryfikacje przynajmniej części nabytej wiedzy teoretycznej, a także swoich własnych opinii.

\section{Refleksja jako niezbędny warunek rozwoju przyszłych i obecnych nauczycieli}

Refleksja może być rozumiana jako „rodzaj myślenia, którego cechą jest ustawiczny namysł, rozważanie czegoś, dociekanie, ważenie problemu, jego różnych stron" (Kwiatkowska, 2008: 64). Tak postrzegana refleksja ma charakter 'wiedzotwórczy', gdyż stwarza możliwość zastanowienia się nad wartością i znaczeniem zastosowanej wiedzy praktycznej. Nie wyklucza to również namysłu nad znaczeniem teorii akademickiej w danym przypadku. Ponadto, refleksja nad 
Wpływ praktyk nauczycielskich na rozwój refleksyjności studentów filologii...

działaniem - czy to obserwowanego nauczyciela, czy własnym - prowadzić może do uświadomienia sobie tzw. teorii osobistych nauczyciela, czyli indywidualnych przekonań i reprezentacji dotyczących różnych aspektów procesu dydaktycznego (Mizerak, 1999 w Szymankiewicz, 2013: 46). Profesjonalny nauczyciel to nie racjonalny technokrata stosujący teorię naukową w praktyce, ale refleksyjny praktyk, który poprzez namysł nad działaniem dochodzi do zrozumienia konkretnych sytuacji i modyfikowania zachowań.

Cechą charakterystyczną teorii osobistych jest to, że oddziałują one w sposób nieuświadomiony na praktykę nauczyciela, blokując wpływ teorii akademickiej, jeśli pod jakimś względem nie zgadza się ona z uwewnętrznionymi przekonaniami. Taka wiedza osobista musi zostać poddana refleksji, gdyż może stać się kryterium oceniania nowo zdobywanej wiedzy. Dlatego też trzeba ją rozpoznać już na początkowym etapie kształcenia. Sam fakt uświadomienia, że obok teorii akademickiej dysponujemy teorią osobistą jest czynnikiem rozwoju zawodowego nauczycieli (Kwiatkowska, 2008: 123-124). Podobne opinie można znaleźć u Michońskiej-Stadnik (2009) i Myczko (2009), które uznają rozpoznanie teorii osobistych przyszłych nauczycieli, zwłaszcza poprzez odniesienie do własnych doświadczeń szkolnych studentów, za punkt wyjścia dla kształcenia zawodowego.

Dokonując analizy opinii zawartych w pracach wyżej wspomnianych autorek Szymankiewicz (2013: 47) prezentuje główne cele rozwijania refleksyjności przyszłych nauczycieli, do których należą: odkrywanie i modyfikowanie teorii osobistych, konfrontowanie ze sobą różnych rodzajów wiedzy (w tym teorii z praktyką) i budowanie własnej wiedzy praktycznej, rozwijanie krytycznego myślenia i postaw otwartości, zauważenie złożoności i nieoczywistości sytuacji dydaktycznych, rozwijanie autonomii nauczyciela, rozwijanie myślenia twórczego. Szymankiewicz (2013: 47) przedstawia działania podejmowane w ramach kształcenia uniwersyteckiego, w celu rozwijania refleksyjności kandydatów na nauczycieli. Wśród nich wymienia dyskusje z innymi studentami i osobami prowadzącymi zajęcia z metodyki, pedagogiki i psychologii, pracę z Europejskim Portfolio Studenckim, mikrolekcje i ich ocenę, obserwacje i komentarz krytyczny lekcji innych nauczycieli, autoewaluację własnych lekcji prowadzonych w ramach praktyk szkolnych, prowadzenie dzienniczka praktyk, przygotowanie raportu z praktyk, a także rozmowy z nauczycielem, opiekunem praktyk.

W tym miejscu należy zwrócić szczególną uwagę na specyfikę refleksji dokonywanej przez nauczycieli języków obcych, których teorie osobiste, jak pisze Werbińska (2006: 32), wywodzą się bezpośrednio z doświadczeń powstałych podczas własnej nauki języka obcego. Nauczyciel przekonany, „że istotą nauki języka jest pamięciowe opanowanie reguł gramatyki i obszernego zasobu słownictwa, mimo deklarowania słuszności podejścia komunikacyjnego, 
będzie poświęcał więcej czasu i uwagi ćwiczeniom gramatycznym niż przeprowadzaniu scenek komunikacyjnych" (Szymankiewicz, 2013: 47). Podobnego zdania jest Michońska-Stadnik (2009: 97), która uważa, że „nauczyciele języków obcych posiadają określone opinie na temat samego nauczanego języka (np., że jest to język trudny), sposobów jego nauczania (np. najważniejsza jest gramatyka; uczeń nie może popełniać błędów; najważniejsze jest porozumiewanie się), a także samych uczniów". Autorka kontynuuje pisząc, że z wcześniej zdobytych doświadczeń edukacyjnych przyszły nauczyciel może przejąć różne opinie na temat nauczania i uczenia się języka, które jednocześnie będą związane z jego pojmowaniem istoty samego języka. „W konsekwencji, należy oczekiwać, że uczenie się języka będzie rozumiane zależnie od przyjmowanej ogólnej koncepcji całego procesu" (Michońska-Stadnik, 2009: 101). Według Martineza (2008: 118) subiektywne teorie na temat procesu uczenia się i nauczania języka mogą być wykorzystane jako wprowadzenie do kursu dydaktyki przedmiotowej. Mogą także posłużyć do rozwinięcia u przyszłych nauczycieli świadomości metakognitywnej siebie samego jako ucznia, procesu uczenia się języka, a także świadomości istnienia i stosowania strategii uczenia się. Podsumowując, refleksja nauczyciela języka obcego może dotyczyć zarówno postrzegania specyfiki i trudności przyswajania samego języka, efektywnych sposobów nauczania języka (np. nauczania bardziej nakierowanego na komunikację, nauczania wymowy, słownictwa czy miejsca gramatyki w nauczaniu języka obcego), a także specyfiki samych uczniów i ich strategii uczenia się języka.

Refleksja zawodowa powinna stanowić immanentną cechę zawodu nauczyciela, gdyż dzięki niej nauczyciel może zrezygnować z działań stereotypowych i rutynowych (Czerpaniak-Walczak, 1995). Wśród zalet refleksyjnego kształcenia nauczycieli można wymienić: większą zdolność nauczycieli do strukturyzacji sytuacji i problemów, łatwość definiowania celów ucznia, zdolność opisu i analizy własnego funkcjonowania w relacjach interpersonalnych, umiejętność nawiązywania kontaktów interpersonalnych z uczniami, osiąganie wyższego stopnia satysfakcji z pracy, silniejsze poczucie bezpieczeństwa i pewności siebie a także uznanie samodzielności ucznia. Należy jednocześnie pamiętać o tym, że kształcenie refleksyjne uwarunkowane jest takimi czynnikami jak biografia, wiedza potoczna, tradycja, i środowisko. Może zdarzyć się tak, że rozwój refleksyjności będzie hamowany przez silne zorientowanie nauczycieli na siebie, niechęć do samokrytyki czy silne wpływy osobiste. Inne czynniki blokujące rozwój refleksyjności to brak odpowiedniej wiedzy pedagogicznej i psychologicznej, wiedzy o alternatywnych sposobach działania i umiejętności ich oceniania, brak analitycznych umiejętności i badania własnej praktyki, czy też ze względu na rozbieżność między koncepcją kształcenia nauczycieli a założeniami refleksyjnego nauczania. Dlatego też zarówno przyszli jak 
Wpływ praktyk nauczycielskich na rozwój refleksyjności studentów filologii...

i obecni nauczyciele powinni być świadomi jaki rodzaj wiedzy i jakie wartości leżą u podstaw ich zachowania w klasie oraz jakie znaczenie mają sposoby wartościowania rzeczywistości wychowawczej. Nauczyciele powinni także mieć możliwość konfrontacji własnej wiedzy i preferowanych wartości z alternatywnymi rozwiązaniami oraz podejmować próby autoidentyfikacji wewnętrznych sprzeczności w subiektywnych teoriach (Dylak, 1996: 35-60).

\section{Praktyki nauczycielskie jako narzędzie do podnoszenia świadomości przyszłych nauczycieli języków obcych}

Jak zauważa Sobierańska (2014: 85), „[w] toczących się w ostatnich latach debatach nad poprawą jakości kształcenia w Polsce problem profesjonalizmu nauczycieli stał się kluczowym zagadnieniem. Oczywistym wydaje się fakt, że z myśleniem o edukacji i jakości przedszkoli czy szkół związany jest namysł nad efektywnym przygotowaniem i doskonaleniem kadr pedagogicznych. W centrum tych zainteresowań pojawia się pytanie o to, jak kształcić przyszłych nauczycieli, aby mogli oni pełnić przypisaną im rolę w demokratycznym i elastycznym systemie szkolnym. Rozważaniom tym często towarzyszy niepokój dotyczący problemu pojęciowego rozumienia teorii i praktyki, możliwych relacji między nimi oraz implikacji przyjętych założeń, zarówno dla kształcenia, jak i aktywności zawodowej nauczycieli". Zauważanie związków pomiędzy teoretycznymi podstawami zawodu a codzienną praktyką wydaje się być wyjątkowo istotne w zawodach, które, jak pisze ta sama autorka, "charakteryzują złożona struktura i złożone warunki realizacji" (Sobierańska, 2014: 85).

Według Parzęckiego (2012: 14) „filozofia studiów nauczycielskich opiera się na paradygmacie wzajemnych powiązań i niezbędnej równowagi między teorią i praktyką, między racjonalizmem i empirią, czyli myśleniem opartym na rozumie, doświadczeniu i przeżyciach". Efektywnemu nauczycielowi języków obcych do profesjonalnego wykonywania swoich obowiązków potrzebna jest harmonijna symbioza pomiędzy nabytą teorią a praktyką zdobytą w sytuacjach dydaktyczno-wychowawczych. Nie należy więc postrzegać nauczyciela jedynie jako biernego wykonawcy założeń teorii akademickich, ale także jako refleksyjnego praktyka, który w swojej codziennej pracy weryfikuje prawdziwość poznanych wcześniej teorii.

Idealnym momentem na weryfikacje prawdziwości teorii akademickich i dokonywanie pierwszych refleksji wydaje się etap kształcenia przyszłych nauczycieli i ich udział w praktykach nauczycielskich. Gabryś-Barker (2012: 68) opisuje studentów jako przyszłych profesjonalistów, którzy przechodzą przez traumatyczne doświadczenia w konfrontacji z głęboko zakorzenionym wyobrażeniem zawodu nauczyciela, które tworzą dezorientujący kontrast pomiędzy 
teorią, którą otrzymali w trakcie studiów, a tym z czym na co dzień spotykają się w klasie językowej. Postrzeganie klasy jako wyidealizowanego obrazu w zderzeniu z doświadczaną rzeczywistością sprawia, że kandydaci na nauczycieli przyjmują inną postawę nakierowaną na przetrwanie. Jeżeli poznają szkolną rzeczywistość podczas swoich praktyk nauczycielskich, będą mieli możliwość zweryfikowania swoich wyobrażeń o zawodzie nauczyciela i podjęcia bardziej przemyślanych i świadomych decyzji dotyczących ich przyszłej kariery nauczycielskiej.

Obserwacja i prowadzenie zajęć pozwala na rzetelną ocenę przydatności teoretycznej wiedzy w klasowych warunkach podczas samodzielnego prowadzenia zajęć lekcyjnych. Zdarza się całkiem często, że to co z perspektywy doświadczonego studenta wydaje się łatwym materiałem językowym do opanowania, okazuje się trudne do wytłumaczenia uczniom. Przyszli nauczyciele ze zdziwieniem przekonują się, że nawet najprostsze struktury gramatyczne stają się wyzwaniem, kiedy trzeba je wytłumaczyć innym. Takie sytuacje pozwalają na refleksję na temat trudności przyswajania języka obcego oraz na temat doboru materiałów do wykorzystania na zajęciach.

\section{Praktyki pedagogiczne w oczach studentów - badanie}

Jak już zostało wcześniej wspomniane, proces rozwijania refleksyjności nauczycielskiej może rozpocząć się już podczas studiów. Pozwoli to na stworzenie bardziej realnego obrazu rzeczywistości edukacyjnej oraz na podjęcie bardziej przemyślanych decyzji na temat wyboru przyszłej ścieżki kariery zawodowej. Idealnym momentem wydaje się okres odbywania praktyk nauczycielskich, podczas których przyszli pedagodzy po raz pierwszy stykają się z autentycznym kontekstem edukacyjnym. Dlatego też badanie opisane poniżej miało na celu uzyskanie większej ilości informacji na temat potencjalnego wpływu praktyk nauczycielskich na rozwój refleksyjności u przyszłych edukatorów.

\subsection{Cel badania}

Badanie miało na celu uzyskanie informacji na temat wpływu odbywania praktyk studenckich na wzrost świadomości studentów filologii angielskiej związanej z wykonywaniem w przyszłości zawodu nauczyciela języka obcego.

\subsection{Uczestnicy}

W badaniu uczestniczyło czterdziestu sześciu studentów trzeciego roku Katedry Filologii Angielskiej Państwowej Wyższej Szkoły Zawodowej w Koninie. Średnia wieku uczestników wynosiła $n=21,5$. Grupa składała się z trzydziestu 
Wpływ praktyk nauczycielskich na rozwój refleksyjności studentów filologii...

jeden kobiet i piętnastu mężczyzn. Wszyscy uczestnicy badania mieli za sobą około 15 lat nauki języka angielskiego a ich wiedza językowa była na poziomie C1 według Europejskiego systemu opisu kształcenia językowego. Semestr, podczas którego przeprowadzone było badanie był ich ostatnim semestrem studiów pierwszego stopnia. Wszyscy uczestnicy na pierwszym roku swoich studiów wybrali moduł pedagogiczny, który wymagał od nich odbycia praktyk pedagogicznych na każdym roku studiów licencjackich. Będąc na trzecim roku studiów, studenci mieli za sobą kilkadziesiąt godzin obserwacji klasowych i około trzydziestu godzin przeprowadzonych zajęć. Praktyka na ostatnim semestrze studiów składała się z 15 godzin obserwacji i aż 45 godzin prowadzenia zajęć lekcyjnych. Studenci odbywali praktyki w różnego rodzaju szkołach. Najwięcej, bo aż dwunastu studentów, nauczało w szkołach ponadgimnazjalnych, ośmiu uczestników odbywało swoje praktyki nauczycielskie w gimnazjach, a pozostała piątka studentów w szkołach podstawowych. Wszystkie praktyki pedagogiczne odbywały się u wcześniej przeszkolonych nauczycieli współpracujących z uczelnią w ramach programu „Efektywne praktyki, efektywny nauczyciel”.

\subsection{Narzędzia i procedura}

W celu uzyskania danych do analizy uczestnicy wzięli udział w krótkim badaniu ankietowym, wykonanym zaraz po odbyciu praktyk, podczas którego mieli za zadanie odpowiedzieć na kilka pytań dotyczących ewentualnych zmian zachodzących w ich postrzeganiu specyfiki zawodu nauczyciela. Ankieta zawierała tylko cztery pytania w języku polskim.

W pytaniu pierwszym, studenci mieli za zadanie stwierdzić czy udział w praktykach nauczycielskich miał wpływ na ich postrzeganie zawodu nauczyciela. W kolejnym pytaniu respondenci musieli zdecydować czy zmiany w postrzeganiu specyfiki zawodu nauczyciela utwierdziły ich w przekonaniu, że właśnie ten zawód powinni wybrać w przyszłości, czy też skłaniają się do szukania innego powołania. Pytanie trzecie miało za zadanie ustalić w jakim stopniu i czego dokładnie dotyczyły zmiany w postrzeganiu specyfiki zawodu nauczyciela. Studenci mieli do wyboru takie aspekty pracy nauczyciela jak: kontakt z uczniami podczas zajęć, utrzymanie dyscypliny na lekcjach, przeprowadzanie zajęć zgodnie z wcześniej przygotowanym planem zajęć, użycie języka pierwszego podczas zajęć, wykorzystanie pomocy dydaktycznych oraz różnorodnych form prowadzenia zajęć, testowanie i dostarczanie informacji zwrotnej, poprawianie błędów uczniowskich, a także dokumentacja szkolna. Do każdego z wymienionych elementów pracy nauczyciela studenci mieli zastosować skalę Likerta od 1 do 5, gdzie 1 oznaczało w małym stopniu, a 5 oznaczało w dużym stopniu. Ostatnie pytanie było pytaniem otwartym, w którym studenci mogli zamieszczać 
dodatkowe komentarze. Po wypełnieniu ankiety przeprowadzone zostały wywiady grupowe, które polegały na tym, że studenci zostali podzieleni na cztery grupy, dwie grupy po dwunastu uczestników i dwie po jedenastu uczestników. Podczas każdego z 45 minutowych spotkań studenci mogli otwarcie wyrażać swoje opinie na temat odbytych praktyk nauczycielskich, a także ich wpływu na postrzeganie zawodu nauczyciela. Prowadzący od czasu do czasu stymulował rozmowę konkretnymi pytaniami w celu uzyskania potrzebnych danych.

\subsection{Prezentacja wyników}

Według 78\% respondentów, zmiany w postrzeganiu specyfiki zwodu nauczyciela wynikające $z$ uczestnictwa w praktykach zawodowych utwierdziły ich w przekonaniu, że wybór zawodu nauczyciela to właściwy wybór na przyszłość. Zaledwie $22 \%$ uczestników stwierdziło, że uczestnictwo w praktykach przekonało ich o konieczności poszukiwania innej drogi zawodowej. Analiza danych uzyskanych w kolejnym pytaniu ankiety dowiodła, że największe zmiany w postrzeganiu specyfiki nauczyciela zaszły w nawiązaniu do kontaktu z uczniami podczas zajęć $(4,63)$ oraz wykorzystaniu różnorodnych form prowadzenia zajęć $(4,47)$. Kolejne aspekty wymienione przez studentów to wykorzystanie pomocy dydaktycznych $(3,99)$, i poprawianie błędów uczniowskich $(3,58)$. Utrzymanie dyscypliny na lekcjach $(3,33)$, użycie języka pierwszego podczas zajęć $(3,14)$, a także przeprowadzanie zajęć zgodnie z wcześniej przygotowanym planem zajęć $(3,25)$ to zagadnienia, które zajęły kolejne miejsca na liście respondentów. Ostatnie dwa miejsca zajęły testowanie i dostarczanie informacji zwrotnej $(2,86)$, a także dokumentacja szkolna $(2,53)$.

Niewielu studentów odpowiedziało na ostatnie pytanie, jednakże nawet nieliczne komentarze, które zostały zamieszczone w ankietach, dostarczyły kilku ciekawych informacji. Oto tylko kilka z nich:

> Nie zdawałam sobie sprawy, że zawód nauczyciela wymaga aż takich zdolności psychologicznych i międzyludzkich. Stworzenie więzi i zaufania to trudna część bycia nauczycielem.

$>$ Chyba jednak nie będzie ze mnie dobry nauczyciel. Patrzqc na to jak nauczycielka odnosi się do swoich uczniów wiem, że ja bym tak nie potrafit. Chyba brak mi empatii...

$>$ Zawsze mojq największq obawq była dyscyplina i umiejętność zapanowania nad uczniami w klasie. Podczas obserwacji zauważyłam, że nauczycielka świetnie dawała sobie radę z dyscyplinq. Może to wcale nie jest takie trudne. Może po prostu brak mi pewności siebie.

Podczas wywiadów grupowych prowadzący poprosił studentów o uzasadnienie swoich wyborów odnośnie zostania nauczycielem. Wśród najczęściej 
Wpływ praktyk nauczycielskich na rozwój refleksyjności studentów filologii...

wymienianych powodów przemawiających za podjęciem zawodu nauczyciela, studenci wskazywali na pozytywny aspekt pracy z młodymi uczniami, możliwość dalszego kształcenia się oraz łatwość znalezienia pracy po studiach. Oprócz tego, dla niektórych respondentów był to wybór od samego początku studiów. Kilku studentów zwróciło uwagę na motywujący aspekt pracy nauczyciela związany z możliwością nauczenia kogoś, przekazania swojej wiedzy i doświadczenia. Jeszcze inni respondenci skłaniali się w kierunku bardziej pragmatycznych zalet zwodu nauczyciela, takich jak oferta pracy w rodzinnym mieście, mimo wszystko lepsze perspektywy niż w innych profesjach, wskazywali też na zawód nauczyciela jako na 'dobry start'. Na drugim końcu skali znalazły się powody, dla których podjęcie pracy nauczyciela nie jest wskazane jako przyszła droga zawodowa. Wśród najczęściej wymienianych znalazły się: brak wymaganych cech, stres, brak cierpliwości i charyzmy, małe szanse na samorealizację, oraz zbyt małe wynagrodzenie. Respondenci wskazali także na specyfikę środowiska nauczycieli jako grupy 'odpychającej', a także na zbyt dużą odpowiedzialność prawną. Kilkoro studentów zniechęcała też zbyt duża ilość pracy nad dokumentacją szkolną i specyfika pracy z 'trudnym uczniem'.

Zdecydowana większość studentów stwierdziła, że obecny program studiów przygotowuje ich dobrze do wykonywania zawodu nauczyciela, a wśród proponowanych zmian znalazły się takie postulaty jak: zwiększona ilość godzin praktycznej nauki języka angielskiego, wprowadzenie przedmiotów pozwalających na lepsze, praktyczne przygotowanie do zawodu nauczyciela, zwiększenie ilości godzin praktyk zawodowych, a także prośba o więcej porad jak radzić sobie z uczniami na zajęciach. Zapytani o ewentualne zmiany w obecnej formule praktyk studenci wskazali na większą potrzebę warsztatów przygotowujących do prowadzenia zajęć, zwiększenie ilości godzin prowadzących w stosunku do godzin obserwowanych, potrzebę rozmów po odbyciu praktyk i większe zaangażowanie nauczycieli/opiekunów praktyk.

Zapytani o ogólne wrażenia z odbytych praktyk, studenci stwierdzili, iż zostali należycie przygotowani do praktyki pedagogicznej, a nauczyciele metodycy i wykładowcy z życzliwością i cierpliwością odpowiadali na dodatkowe pytania, wyjaśniali jak postępować w trudnych sytuacjach w klasie, bardzo solidnie przygotowali uczących się do obserwacji zajęć, a także do przygotowywania konspektów lekcyjnych. Część studentów zwróciło uwagę na zbyt teoretyczne nauczanie dydaktyki, co nie miało wiele wspólnego z praktyką szkolną. Kilka osób podkreśliło jednak, iż miało niewielkie problemy z wypełnieniem dokumentacji dotyczącej praktyk, co ich zdaniem związane było z niedostatecznym wytłumaczeniem stanu rzeczy przez opiekuna praktyk.

Analizując wypowiedzi studentów na temat nabytych umiejętności można zauważyć pewne tendencje, które pozwalają na ich podział na pedagogiczne 
i osobowościowe. Wśród tych pierwszych znalazły się takie sprawności jak umiejętność planowania zajęć lekcyjnych (sporządzanie konspektu lekcyjnego), gospodarowania czasem, utrzymania dyscypliny w klasie, oraz oceniania. 'Umiejętności' związane z osobowością studenta/nauczyciela dotyczyły pozbycia się tremy i stresu, obowiązkowości, sumienności, cierpliwości, zaradności, komunikatywności, kreatywności, otwartości na potrzeby uczniów, a także motywowania uczniów do pracy na zajęciach.

Pod koniec każdego z wywiadów grupowych studenci pytani byli o ewentualne trudności napotkane podczas praktyk nauczycielskich. Także w tym przypadku odpowiedzi udzielane przez uczestników badania nie odbiegały daleko od przewidywań badacza. Do najczęściej wskazywanych wyzwań należały problemy z utrzymaniem dyscypliny, trema, stres, czasowe zrealizowanie zaplanowanego materiału, problemy z motywowaniem niektórych uczących się (sporadycznie), małe zaangażowanie nauczyciela, opiekuna praktyk, problemy ze sporządzaniem konspektów lekcyjnych (incydentalnie), a także zbyt duża liczba dokumentów do uzupełnienia.

\subsection{Omówienie wyników}

Patrząc na uzyskane wyniki wyraźnie widać, że dla zdecydowanej większości uczestników praktyki nauczycielskie miały bezpośredni wpływ na ich postrzeganie zawodu nauczyciela. Możliwość bezpośredniej weryfikacji posiadanej wiedzy teoretycznej w kontekście klasowym wydaje się być nieocenionym doświadczeniem dla studentów uczestniczących w praktykach. Czym innym jest mówić o pracy nauczyciela na podstawie teoretycznych rozważań, a czym innym jest możliwość poprowadzenia zajęć lekcyjnych. Na pewno wielu z nas pamięta swoje pierwsze samodzielnie poprowadzone lekcje, które pomimo obecności nauczyciela, opiekuna były stresującym przeżyciem. Jednakże, nawet jeżeli tamte wspomnienia są do dzisiaj bolesne, to przynajmniej pozwoliło nam to w podjęciu bardziej przemyślanych decyzji dotyczących dalszego kontynuowania raz obranej drogi zawodowej. Oprócz tego możliwość weryfikacji teorii w praktycznym kontekście pozytywnie wpływa na symbiozę środowiska akademickiego i nauczycielskiego, które wydaje się, że odsunęły się od siebie znacząco. Weryfikacja naszej teoretycznej wiedzy w kontekście klasowym jest tym bardziej istotna, iż znacząca ilość publikacji dydaktycznych została napisana przez autorów z innych krajów i kręgów kulturowych, którzy czasami nie są w stanie wziąć pod uwagę polskiego kontekstu edukacyjnego.

Refleksja studentów dotyczyła wielu różnorodnych aspektów nauczania. Nie powinno dziwić, że najwięcej refleksji poświęcono nawiązywaniu kontaktów między nauczycielem a uczniem. Z moich własnych doświadczeń wyraźnie 
Wpływ praktyk nauczycielskich na rozwój refleksyjności studentów filologii...

wynika, że studenci idący na praktyki bardzo często obawiają się sytuacji, w której nie będą potrafili nawiązać pozytywnej relacji z uczniami. Czasami taka zbyt eksplicytna próba nawiązania przyjaznych kontaktów z uczniami sprowadza na studenta kłopoty z utrzymaniem dyscypliny. Podobną opinie wyraża GabryśBarker (2012: 68), która pisze o tym, że studenci są bardzo skupieni na budowaniu swojego autorytetu albo przez przyjęcie postawy bardzo przyjaznej, albo bardzo autorytatywnej. Co ciekawe utrzymanie dyscypliny na zajęciach nie znalazło się wśród głównych tematów dokonywanej refleksji. Być może na tym etapie zdobywania doświadczenia nauczycielskiego studenci nastawieni są głównie na przetrwanie. Dopiero po jakimś czasie studenci zaczynają zwracać uwagę na specyfikę kontrolowania grupy uczniowskiej.

Część zagadnień, na temat których studenci dokonywali refleksji związane były z technicznymi aspektami prowadzenia lekcji, takimi jak pomoce dydaktyczne, różnorodność form prowadzenia zajęć, a także przeprowadzanie zajęć zgodnie z wcześniej przygotowanym planem lekcji. Taka tematyka dokonywanej refleksji nie powinna dziwić doświadczonych nauczycieli, którzy pamiętają, iż na początku drogi bardziej zwracamy uwagę na to, żeby nie pomylić kroków niż na krajobrazy dookoła nas. Z czasem doświadczenie i pozytywnie rozumiana rutyna pozwolą na dokonywanie refleksji nad bardziej złożonymi aspektami pracy nauczyciela. Według respondentów, testowanie i dokumentacja szkolna nie były tematami wymagającymi refleksji. Być może dlatego, że w czasie praktyk studenci nie mają zbyt wielu okazji do testowania swoich podopiecznych, a dokumentacja szkolna jest omawiana w ramach przygotowania do praktyk i jako nieodzowny element pracy nauczyciela nie jest tematem przemyśleń studenckich.

Ciekawe informacje można uzyskać z dodatkowych komentarzy i uwag zamieszczonych w ankiecie. Analizując tych kilka wpisów wyraźnie widać, że studenci dokonywali refleksji na temat specyfiki pracy nauczyciela, ale także, co jest równie ważne, na temat swoich cech osobowościowych i przebiegu zajęć lekcyjnych. Gdyby tylko nauczycielom starczyło wytrwałości i systematyczności, mogłoby się okazać, że dzienniki nauczycielskie albo jakakolwiek inna forma dokonywania refleksji może stać się nieocenionym źródłem motywacji nauczycielskiej i inspiracji na kolejne dni pracy z uczniami i nad samym/samą sobą. Być może dzięki systematycznej refleksji wypalenie zawodowe i codzienne frustracje nauczycieli nie byłyby tak częste.

Badając powody zostania nauczycielem w przyszłości, bądź też szukania innej drogi zawodowej, wyraźnie można zauważyć, że studenci w swoich wyborach często kierują się stereotypowym, zasłyszanym wyobrażeniem osoby nauczyciela. Klasycznym powodem, który pojawia się chyba najczęściej w rozmowach ze studentami jest brak cierpliwości. Z jednej strony takie odpowiedzi nie dziwią 
nikogo, kto zetknął się ze studentami podczas praktyk nauczycielskich, z drugiej jednak strony studenci powinni dać sobie chociaż mały kredyt zaufania i nie szukać powodów, które nie mogą zostać zweryfikowane inaczej niż podczas dłuższego okresu pracy w zawodzie nauczyciela. Może okazać się, że z czasem studenci/nauczyciele dojdą do wniosku, że może ich przekonanie o braku wymaganych cech, w tym cierpliwości, nie pokrywa się z rzeczywistością. Ciekawe są także opinie na temat zbyt dużej odpowiedzialności prawnej i pracy z uczniem trudnym. Wydaje się, że to kolejne stereotypowe podejście do zawodu nauczyciela, który kojarzy się głównie z odpowiedzialnością za uczniów, którzy przede wszystkim sprawiają kłopoty wychowawcze.

Z rozmów wynika także, że jest grupa studentów, którzy postrzegają pracę z uczniami, szczególnie tymi najmłodszymi, jako główny powód przemawiający za podjęciem zawodu nauczyciela w bliskiej przyszłości. Obiecujące jest też to, że dla kilku z respondentów możliwość przekazywania nabytej wiedzy i doświadczenia jest tym, co skłania ich do wyboru zawodu nauczyciela. Można mieć nadzieję, że w przyszłości przynajmniej część z nich stanie się nauczycielami z powołania, którzy będą 'zarażać' uczniów swoją pasją. Jednocześnie trochę zaskakują opinie związane z perspektywiczną naturą zawodu nauczyciela, a dokładnie z łatwością znalezienia zatrudnienia. Wydawać by się mogło, że w dzisiejszych czasach rynek nauczycielski jest bardzo nasycony i znalezienie pracy w placówce edukacyjnej nie należy do najłatwiejszych. Jednakże absolwenci filologii często zakładają swoje własne szkoły albo podejmują pracę w prywatnych szkołach językowych.

Wracając do opinii na temat praktyk nauczycielskich, nie powinny dziwić oczekiwania studentów, które związane są z nadaniem praktykom nauczycielskim jeszcze bardziej pragmatycznego wymiaru. Dla większości z nich praktyki nauczycielskie to doskonały i często jedyny moment na zdobycie praktycznej wiedzy związanej z nauczaniem, którą później część z nich wykorzysta w pracy zawodowej. Brak doświadczenia zawodowego sprawia, że dla większości z nich prowadzenie zajęć w ramach praktyk nauczycielskich jest stresującym wyzwaniem, dlatego też nie powinny zdumiewać prośby o większą ilość wskazówek jak radzić sobie z uczniami i warsztatów przygotowujących do prowadzenia zajęć. Bardzo cieszy fakt, że respondenci wskazali na potrzebę zwiększenia ilości godzin prowadzonych, a także na potrzebę rozmów po odbyciu praktyk. Dzięki takim spotkaniom studenci mieliby idealną okazję do rozwijania swojej refleksyjności i autonomii.

Czasami można spotkać się z opiniami, że dla studentów odbywanie praktyk to zło konieczne i że zrobią dużo, żeby praktyki odbyły się jak najmniej inwazyjnie. Jednakże uzyskane $w$ badaniu wyniki wskazują na trend zupełnie inny i dowodzą, że w dzisiejszych czasach młodzi ludzie pragmatycznie podchodzą 
Wpływ praktyk nauczycielskich na rozwój refleksyjności studentów filologii...

do swoich obowiązków, planują swoją przyszłość zawodową i tego samego oczekują od nauczycieli, opiekunów i mentorów praktyk nauczycielskich. Stąd też postulat o większe zaangażowanie nauczycieli/opiekunów praktyk. O pragmatycznym podejściu do odbywania praktyk studenckich mogą świadczyć opinie na temat nabytych w trakcie praktyk umiejętności. Oczywiście należy jednocześnie wyraźnie podkreślić, że zbyt krótki okres trwania praktyk może dawać nie do końca autentyczny stan deklarowanych umiejętności, niemniej jednak sama deklaracja na temat nowych umiejętności napawa optymizmem i może być dowodem na wpływ praktyk nauczycielskich na rozwijanie refleksyjności studenckiej. Większość z zadeklarowanych umiejętności dotyczy technicznych aspektów prowadzenia zajęć takich jak planowanie zajęć, czasu, dyscypliny, a także oceniania. Jak już zostało wcześniej napisane, na samym początku drogi nauczycielskiej młodzi pedagodzy skupiają swoją uwagę głównie na 'technikach przetrwania', które pozwalają na doprowadzenia zajęć do szczęśliwego końca. Jednakże, pozytywnym wynikiem rozmów ze studentami jest też odkrycie, że studencka refleksja dotyczyła również aspektów osobowościowych i profesjonalnego zachowania wymaganego od nauczycieli podczas zajęć. Fakt, że studenci poddawali refleksji siebie samych i swoje zachowanie wskazywać może na to, że dzięki praktykom nauczycielskim kandydaci na przyszłych nauczycieli przeszli na wyższy poziom refleksji.

\section{Konkluzje i sugestie na przyszłość}

Ilość respondentów i brak analizy statystycznej nie pozwalają na wyciąganie dalekosiężnych wniosków z badania. Jednakże wnioski, które można wyciągnąć pozwalają na stwierdzenie, iż świadome zaangażowanie w proces refleksji nad własnymi działaniami zwiększa nie tylko świadomość studentów na temat przyszłych wyborów zawodowych, procesu nauczania, ale także na dokonywanie udanej autorefleksji. Teoria, z którą zapoznawani są studenci podczas toku studiów, powinna być skonfrontowana z codzienną praktyką nauczycielską. Refleksja dokonywana już na etapie przygotowującym do zawodu nauczyciela może okazać się doskonałym narzędziem do pełniejszego zrozumienia samych siebie oraz specyfiki nauczycielskiej profesji, a także zapewnić mniej bolesne przejście od wyidealizowanego obrazu nauczyciela do bardziej realistycznej wizji. Dzięki temu zachowania przyszłych nauczycieli staną się bardziej celowe i przemyślane, co może mieć wpływ na bardziej świadomy wybór przyszłego zawodu i na bardziej efektywne nauczanie. Zdając sobie sprawę z potencjalnych trudności podczas odbywania praktyk, być może uczelniani opiekunowie praktyk powinni poświęcić więcej czasu na ewaluację praktyk albo cykliczne spotkania ze studentami. Ewaluacja praktyk nie powinna sprowadzać się 
tylko do zbierania dokumentacji. Cykl spotkań ze studentami przed odbyciem praktyk i po ich wykonaniu pozwoli obniżyć stres, nabrać więcej pewności siebie, i być może wpłynie na większą samodzielność studentów podczas dalszych etapów praktyki nauczycielskiej. Dla samego opiekuna praktyk takie spotkania mogą stanowić idealną okazję do refleksji nad procesem edukacyjnym. Być może warto także zastanowić się nad większym zaangażowaniem nauczycieli opiekunów praktyk w wymianę doświadczeń i opinii. Na pewno duże znaczenie będzie miał przemyślany dobór nauczycieli na poziomie szkół. Należy poszukać takich pedagogów, którzy zrozumieją wagę praktyk studencki i którzy będą gotowi na przyjęcie na siebie roli mentorów.

\section{BIBLIOGRAFIA}

Czerepaniak-Walczak, M. 1995. „Refleksja zawodowa nauczyciela-wychowawcy, jej przedmiot, źródła, rola" (w) Nauczyciele Języków Obcych w dobie przemian (red. E. Zawadzka). Kraków: Impuls: 301-302.

Dylak, S. 1996. „Kształcenie nauczycieli do refleksyjnej praktyki: zarys genezy, istoty i rozwoju koncepcji (studium literaturowe)". Rocznik Pedagogiczny 19, 35-60.

Gabryś-Barker, D. 2012. Reflectivity in pre-service teacher education. A survey of theory and practice. Katowice: Wydawnictwo Uniwersytetu Śląskiego.

Kwiatkowska, H. 2008. Pedeutologia. Warszawa: Wydawnictwa Akademickie i Profesjonalne. Martinez, H. 2008. "The subjective theories of student teachers. Implications for teacher education and research on learner autonomy" (w) Learner and teacher autonomy. Concepts, realities and responses (red. T. Lamb, H. Reinders). Amsterdam/Philadelphia: John Benjamins Pubishing Company: 103-124.

Michońska-Stadnik, A. 2009. „Od wyboru podręcznika do rozwoju autonomicznego poznania. Rola refleksji w kształceniu nauczycieli języków obcych" (w) Nauczyciel języków obcych dziś i jutro (red. M. Pawlak, A. Mystkowska-Wiertelak, A. Pietrzykowska). Poznań-Kalisz: Wydział Pedagogiczno-Artystyczny UAM w Kaliszu: 97-106.

Myczko, K. 2009. „Kształcenie nauczycieli języków obcych i praktyka zawodowa” (w) Nauczyciel języków obcych dziś i jutro (red. M. Pawlak, A. Mystkowska-Wiertelak, A. Pietrzykowska). Poznań-Kalisz: Wydział Pedagogiczno-Artystyczny UAM w Kaliszu. 157-166.

Parzęcki, P. 2012. „,'Q' praktyce kształcenia nauczycieli. Wstęp do dyskusji” (w) Praktyki pedagogiczne ważnym ogniwem w procesie kształcenia nauczycieli edukacji wczesnoszkolnej i przedszkolnej. Teoretyczne i praktyczne aspekty ksztatcenia nauczycieli edukacji wczesnoszkolnej i przedszkolnej (red. M. Krzemiński, B. Oraczewska). Włocławek: Państwowa Wyższa Szkoła Zawodowa we Włocławku: 13-19.

Rozporządzenie Ministra Nauki i Szkolnictwa Wyższego z dnia 17 stycznia 2012 r. w sprawie standardów kształcenia przygotowującego do wykonywania zawodu nauczycieli, DzU Nr 164, poz. 1365, z późn. zm. 
Wpływ praktyk nauczycielskich na rozwój refleksyjności studentów filologii...

Sobierańska, D. 2014. „Praktyki pedagogiczne jako ważne ogniwo w kształceniu nauczycieli - założenia i realizacja projektu" (w) Razem poprzez zmiany w kształceniu praktycznym przyszłych nauczycieli. (red. M. Sieńczewska). Warszawa: Warszawska Firma Wydawnicza. 85-108.

Szymankiewicz, K. 2013. „Kształtowanie refleksyjnych postaw przyszłych nauczycieli języka francuskiego - rola internetowego, dydaktycznego forum dyskusyjnego". Języki Obce w Szkole 01/2013, 46-51.

Werbińska, D. 2006. Skuteczny nauczyciel języka obcego. Warszawa: Fraszka Edukacyjna. http://www.wbc.poznan.pl/Content/9794/ch02s04.html 